\title{
Assessing Rainfall and Temperature Changes in Semi-Arid Areas of Tanzania
}

\author{
Peter Matata $^{1^{*}}$, Magreth Bushesha², John Msindai ${ }^{3}$ \\ ${ }^{1}$ Tumbi Agricultural Research Institute, Tumbi, Tabora, Tanzania \\ ${ }^{2}$ Department of Geography, Open University of Tanzania, Dar es Salaam, Tanzania \\ ${ }^{3}$ Teoflo Kisanji University, Mbeya, Tanzania \\ Email:`matatazp@yahoo.co.uk,magrethbushesha@yahoo.com,jmsindai@gmail.com,gwambene@gmail.com
}

How to cite this paper: Matata, $\mathrm{P} ., \mathrm{Bu}-$ shesha, M. and Msindai, J. (2019) Assessing Rainfall and Temperature Changes in Semi-Arid Areas of Tanzania. American Journal of Climate Change, 8, 173-189. https://doi.org/10.4236/ajcc.2019.82010

Received: June 11, 2018

Accepted: May 2, 2019

Published: May 5, 2019

Copyright (c) 2019 by author(s) and Scientific Research Publishing Inc. This work is licensed under the Creative Commons Attribution International License (CC BY 4.0).

http://creativecommons.org/licenses/by/4.0/

\section{(c) (i) Open Access}

\begin{abstract}
This paper examines the variability of rainfall and temperature in Igunga and Kishapu Districts using time series data (1985 to 2016) from Tanzania Meteorological Agency. The regression analysis results show rainfall variability of $\mathrm{R}^{2}=0.096$ in Igunga and $\mathrm{R}^{2}=0.186$ in Kishapu which implies that about $0.96 \%$ and $1.86 \%$ of the changes in rainfall across the districts are associated with changes in weather variables. A considerable change of amount of rains was evident in Igunga than in Kishapu District. In both districts there was a change of months with the most rains. Generally rainfall showed a decreasing trend in both districts. The paper also examined temperature trends in the two districts; the findings showed an increasing trend throughout October in both districts. From this point of view, higher temperatures can increase evapo-transpiration that in turn can have an effect on moisture for the crops adversely affecting pasture productivity for livestock, and leading to a shortage of water for both crops and livestock. Annual rainfall variability trends, however, increased indicating that annual variability was somewhat a common feature in the study districts. So, districts efforts should be directed towards the support of crop and livestock adjustments in order to buffer impacts of rainfall and temperature variability during critical periods for growing of crops and pastures.
\end{abstract}

\section{Keywords}

Climate Variability, Rainfall, Temperature, Semiarid, Tanzania

\section{Introduction}

The climate in central Tanzania is characterized by low rainfall patterns, punc- 
tuated by storms, droughts and floods; and increasing and decreasing trends in temperature and precipitation [1]. In this study, variability was examined between years as well as between and within growing seasons. Droughts are prevalent and unpredictable in many parts of the country [2]. In drought-stricken, rural and semi-arid regions of Sub-Saharan Africa (SSA), including Tanzania, where poverty is common, livelihoods are largely anchored on farming, pastoralism and agro-pastoralism [3] [4]. Even though there is a long history of droughts in Tanzania, studies show that the frequency of droughts has increased over the past few decades, especially in semi-arid areas such as Dodoma, Shinyanga, Singida, Tabora and some parts of Arusha and Iringa [2] [5] [6]. Rainfall variability data analysed for the period between 1974 and 2005 in semi-arid of Shinyanga Rural District in Tanzania, reported no significant decrease over time. However, decreasing measured rainfall and increasing temperature for the period between 1992 and 2007 were reported in Manyoni, another semi-arid area in Tanzania [5] [7].

Climate studies indicate that mean temperatures and precipitation in the country have changed over time [8]-[13]. The Fifth Report of the Intergovernmental Panel on Climate Change (IPCC) on climate variability in Tanzania provides more evidence on the occurrence of the phenomenon than previous reports [14]. The average annual rainfall of Tanzania shows a very high level of variability over the past years [15]. Literature reveals a high degree of agreement that climate variability and change have already happened, and that they are global phenomena [12] [13] [16] [17]. The proponents of the phenomena are of the view that rainfall is decreasing, while temperature is increasing over time. However, they fail to explain seasonal variability particularly within crop growing seasons over time. Some scholars are of the view that climate variability is not new in semi-arid regions; and that such variability in climate has been affecting smallholder farmers and pastoralists for many decades [18] [19] [20] [21] [22]. According to [6] for example, inter-annual variability of rainfall and temperature in Tanzania is common. Frequent dry spells have resulted in reduced crop yields and increased food shortages leading to food insecurity [5]. Furthermore, annual rainfall data analysis shows a decreasing trend at the rate of $3.3 \%$ per decade, more so in southern Tanzania, while the mean annual temperature has increased by $0.23^{\circ} \mathrm{C}$ per decade during the period between 1960 and 2003 [23]. Both day time and night time temperatures show an increasing trend, particularly during January and February; but nighttime temperatures reveal an increasing trend at $19.8 \%$ per year relative to day time temperature, which increased at 13.6\% per year between 1960 and 2003 [24].

Kishapu and Igunga districts, located in semi-arid areas, have been hard hit by the ongoing climate variability and change. The inhabitants of Kishapu and Igunga have been caught up in the ongoing wave of emigration from dry areas to areas with high rainfall. The movement of the indigenous people with their flocks of livestock from various places in Tanzania to other parts within the 
country, has ravaged forest reserves, game parks and other conservation areas. The movement has been accompanied by conflicts between farmers and pastoralists; and conflicts between conservation authorities and pastoralists. In rainfed agriculture and pastoralism these changes in climate have been characterized by unpredictable patterns of rainfall, leading to poor harvests and scarce pastures. [9] [25] predict more decrease in rainfall in semi-arid regions of Africa than it is at present; and add that if this trend continues, the growing season in semi-arid regions of Africa will be reduced by $20 \%$ in 2050 . While climate variability is differentiated by geographical location [14] [26] [27], there is limited information regarding trends of climate variability in semi-arid ecological zones. Since climate variability is considerably affecting productivity in agriculture and livestock as well as natural resources management in semi-arid areas, a clear understanding of the phenomenon is critically important in order to inform decision making processes when addressing the phenomenon.

Furthermore, this paper describes climate variability in areas which have never been studied before with the view of contributing knowledge on rainfall and temperature trends over time in Igunga and Kishapu districts, semi-arid areas located in western parts of Tanzania. Specifically, the paper assesses: 1) Annual and monthly rainfall and temperature variations; 2) Seasonal variability during crop growing period starting from October to December for a period between 1985 and 2016. This paper's point of view is that rainfall and temperature are among the most important climatic variables for agriculture and livestock keeping systems in semi-arid areas.

\section{Description of the Study Areas}

Igunga and Kishapu districts were selected purposively for the study by being situated in semi-arid regions. Igunga District is located in Tabora Region and lies between latitudes $3^{\circ} 51^{\prime} \mathrm{S}$ and $4^{\circ} 48^{\prime} \mathrm{S}$ of Equator and longitudes $33^{\circ} 22^{\prime} \mathrm{E}$ and $34^{\circ} 8^{\prime} \mathrm{E}$ of Greenwich (Figure 1). Igunga District [28] covers an area of 6912 square kilometres and it is bordered by Kishapu District to the North, Iramba District to the East, Uyui District to the South and Nzega District to the west. The total population is 260,294 and 32,536 household [29] and has a population density of 58 people per square kilometre [29] 65\% of the households own livestock and 32\% practice mixed crop and livestock farming system [28]. Igunga and Kishapu districts were selected purposively for the study by being situated in semi-arid regions. The livestock found in the area comprises cattle, goats, local chicken, donkeys and sheep. It was difficult to separate crop production and livestock keeping in Igunga and Kishapu districts because the majority of livestock keepers also grew crops and vice versa. Agro-pastoralism was most common at Mbutu and Mwamalasa villages which receive relatively very low rainfall.

Igunga District is semi-arid area with temperatures ranging from $20^{\circ} \mathrm{C}$ to $33^{\circ} \mathrm{C}$. It is one of the driest districts in Tanzania with rainfall ranging from 500 


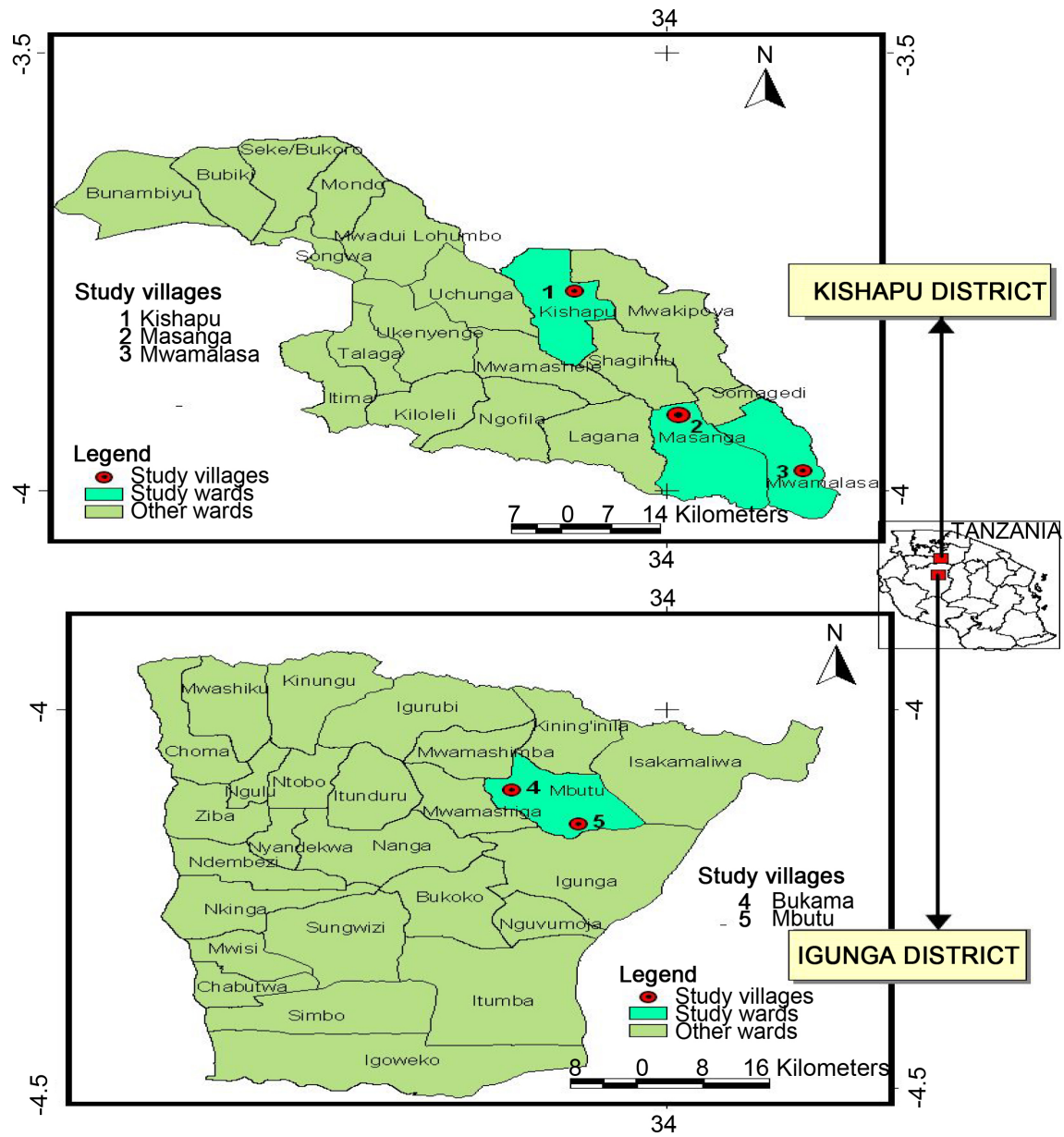

Figure 1. Map of the study area.

$\mathrm{mm}$ to $700 \mathrm{~mm}$ per annum. The rainfall season spans the period from November to April. The southern and south western parts of the district get more rain than the northern and north eastern parts [28]. About three-fifth of the district's population cultivate cotton and sunflower, which are the main cash crops.

Kishapu District covers an area of $9226 \mathrm{~km}^{2}$, and lies between longitudes $36^{\circ} 30^{\prime} \mathrm{E}$ and $33^{\circ} 30^{\prime} \mathrm{E}$ and latitudes $3^{\circ} 45^{\prime} \mathrm{S}$ and $5^{\circ} 00^{\prime} \mathrm{S}$. The total population is 272,999 and 35,500 households with an average household size of 8 people. $89.5 \%$ of the people live in rural areas [30], $75 \%$ own livestock and $39 \%$ practice mixed crop and livestock farming system [31]. The mean annual rainfall in Kishapu lies between $600 \mathrm{~mm}$ and $800 \mathrm{~mm}$ and surface temperature ranges from $16^{\circ} \mathrm{C}$ in June to $30^{\circ} \mathrm{C}$ in October. The area lies at an altitude $1000-1200 \mathrm{~m}$ above sea level. The highest temperature is experienced in October, just before the onset of rainfall. A dry spell normally occurs between mid-January and February [31]. The rainfall regime in both districts is unimodal, which starts in November and ends in April [32]. The major cash crops are cotton, sunflower, groundnuts, green gram onions, pigeon peas and cowpeas. Livestock comprise cattle, goats, sheep and donkeys. The major food crops grown are sweet potatoes, sorghum and maize. Other economic activities are mining and sunflower oil processing. 


\section{Materials and Methods}

Daily and monthly rainfall data for Igunga District from 1985 to 2016 (31 years) and Kishapu Districts for the period 1987-2016 (29 years) were obtained from the Tanzania Meteorological Agency (TMA). Daily rainfall data were summed up into monthly and annual totals. Due to lack of meteorological station in Kishapu District, the study used mean data obtained from Kishapu Meteorological Stations managed by the District Agricultural and Livestock Department (DALDO) located in Kishapu District. However, due to failure of the recorder to submit the readings from meteorological stations to TMA for the period 1985 to 1986, the time frame with continuous meteorological data for rainfall and temperature was reduced to 29 years, covering a period between 1987 and 2016.

Similarly, temperature records available for Kishapu District covered the period from 1987 to 2016 i.e. 29 years recods available instead of 31 years period. Climatic data such as rainfall and temperature were analysed using Excel to generate tables and graphs. SPSS was employed to generate means and variances, skewness and kurtosis which were used to assess the changes in climate [33]. Maximum temperatures are recorded during the day time and thus, play a critical role in controlling evapo-transpiration and drying up of water bodies [23]. On the other hand, minimum temperatures are obtained during the night. For rainfall variability, the analysis focused on annual and seasonal variability trends because variabilty can reveal dry and wet periods over time .

During data analysis, both variability and monthly means were computed. The variability was computed as a deviation from a long-term (annual) mean. The rainfall and temperature annual variability are presented in (Tables 1-4). The hypothesis that the study districts did not experience significant increasing trends in inter-annual rainfall variability for a period between 1985 and 2016 was tested using a p-value at $5 \%$ level of significance. To analyze meteorological data, R-Statistical package was used to perform simple regression analysis for rainfall and temperature data. Several studies have also used in this approach in the past to analyse evidence of climate change [33] [34].

The dependent variable $[Y(j)]$ was the physical factor (mean rainfall, mean minimum temperature, mean maximum temperature) and independent variables (x) was the number of seasons or years (for example, 1986/87 to 2015/16 for rainfall). From the analysis the XY scatter plot with regression line, regression equations together with the R-square (R2) values were established. To determine significance of the trends, F-test was used to test significance of $R^{2}$ at $5 \%$ level.

\section{Results and Discussion}

\subsection{Trends in Monthly Rainfall and Temperature in Kishapu and Igunga Districts}

Rainfall is a major climate parameter with the highest degree of spatial and 
Table 1. Description of monthly rainfall in Kishapu District from 1987-2016.

\begin{tabular}{ccccccccc}
\hline Moth & N & Minimum & Maximum & Mean & Std. Deviation & Variance & Skewness & Kurtosis \\
\hline January & 28 & 25.30 & 328.40 & 116.5857 & 59.70766 & 3565.005 & 1.587 & 4.818 \\
February & 29 & 20.30 & 171.10 & 95.6034 & 37.61550 & 1414.926 & 0.140 & -0.522 \\
March & 29 & 63.10 & 230.70 & 136.7138 & 37.29866 & 1391.190 & 0.295 & 0.531 \\
April & 29 & 11.90 & 213.40 & 109.4241 & 50.70094 & 2570.585 & 0.179 & -0.731 \\
May & 29 & 0.00 & 130.80 & 33.4000 & 31.59972 & 998.542 & 1.453 & 2.189 \\
June & 29 & 0.00 & 8.20 & 0.9828 & 2.30079 & 5.294 & 2.611 & 5.798 \\
July & 29 & 0.00 & 0.00 & 0.0000 & 0.00000 & 0.000 &. &. \\
August & 29 & 0.00 & 12.60 & 0.9621 & 2.63458 & 6.941 & 3.700 & 14.598 \\
September & 29 & 0.00 & 37.40 & 6.0690 & 9.62119 & 92.567 & 1.918 & 3.260 \\
October & 29 & 0.10 & 159.90 & 34.4483 & 43.50720 & 1892.877 & 1.695 & 2.012 \\
November & 29 & 12.10 & 215.90 & 97.4655 & 57.27208 & 3280.091 & 0.686 & -0.276 \\
December & 29 & 10.40 & 449.70 & 141.3552 & 83.27899 & 6935.390 & 1.784 & 5.743 \\
Total & 29 & 2592.20 & 3809.60 & 3051.272 & 273.18319 & $74,629.058$ & 0.600 & 0.662 \\
Average & 29 & 42.80 & 102.20 & 67.7793 & 13.24741 & 175.494 & 0.732 & 1.088 \\
\hline
\end{tabular}

Table 2. Monthly maximum temperature $\left({ }^{\circ} \mathrm{C}\right)$ in Kishapu District (1987 to 2016).

\begin{tabular}{|c|c|c|c|c|c|c|c|c|c|}
\hline 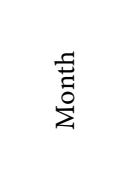 & Z & 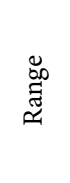 & 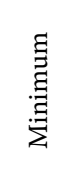 & 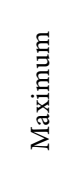 & 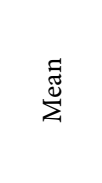 & 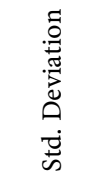 & 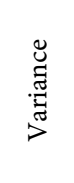 & 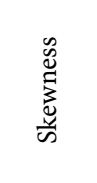 & 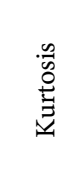 \\
\hline January & 29 & 6.60 & 26.10 & 32.70 & 29.4931 & 1.34215 & 1.801 & -0.344 & 0.995 \\
\hline February & 29 & 4.40 & 28.40 & 32.80 & 30.1241 & 1.28276 & 1.645 & 0.558 & -0.510 \\
\hline March & 29 & 4.40 & 28.40 & 32.80 & 30.1828 & 1.12029 & 1.255 & 0.634 & 0.063 \\
\hline April & 29 & 3.20 & 28.20 & 31.40 & 29.7414 & 0.90811 & 0.825 & 0.107 & -0.906 \\
\hline May & 29 & 3.80 & 27.70 & 31.50 & 29.8414 & 0.93140 & 0.868 & -0.593 & 0.055 \\
\hline June & 29 & 2.10 & 28.90 & 31.00 & 30.0276 & 0.47048 & 0.221 & 0.006 & 0.103 \\
\hline July & 29 & 1.70 & 29.20 & 30.90 & 29.9345 & 0.44503 & 0.198 & 0.569 & -0.373 \\
\hline August & 29 & 1.80 & 29.70 & 31.50 & 30.8724 & 0.43416 & 0.188 & -0.648 & 0.570 \\
\hline September & 29 & 2.00 & 31.50 & 33.50 & 32.3931 & 0.50351 & 0.254 & 0.639 & 0.299 \\
\hline October & 29 & 3.50 & 30.10 & 33.60 & 32.6897 & 0.74563 & 0.556 & -1.853 & 4.531 \\
\hline November & 29 & 9.50 & 24.00 & 33.50 & 31.0172 & 1.85030 & 3.424 & -1.918 & 6.350 \\
\hline December & 29 & 6.80 & 26.80 & 33.60 & 29.7931 & 1.62831 & 2.651 & 0.610 & 0.476 \\
\hline Average & 29 & 1.90 & 29.50 & 31.40 & 30.5103 & 0.41606 & 0.173 & -0.069 & 0.484 \\
\hline
\end{tabular}

temporal variability in Kishapu District. Kishapu District has one rainfall season receiving the highest amount of precipitation in December. The monthly rainfall data for the entire period is positively skewed to the right (0.732) indicating that rainfall data are not normally distributed. The results in this study show high standard deviations implying that rainfall patterns vary highly each month during crop growing season. December recorded throughout the highest amount of 
Table 3. Monthly rainfall in Igunga district from 1985 to 2016.

\begin{tabular}{|c|c|c|c|c|c|c|c|c|}
\hline 营 & $\mathbf{z}$ & 氶 & 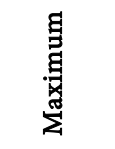 & 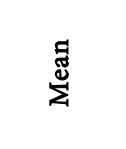 & 莣苛 & 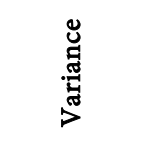 & 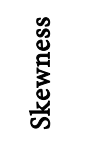 & $\frac{a}{0}$ \\
\hline January & 32 & 0.00 & 328.40 & 110.0469 & 62.49284 & 3905.355 & 1.143 & 3.722 \\
\hline February & 32 & 20.30 & 171.10 & 97.4313 & 37.86505 & 1433.762 & 0.063 & -0.740 \\
\hline March & 32 & 63.10 & 248.20 & 138.1344 & 41.54258 & 1725.786 & 0.713 & 0.860 \\
\hline April & 32 & 11.90 & 213.40 & 112.9844 & 51.10928 & 2612.158 & 0.132 & -0.761 \\
\hline May & 32 & 0.00 & 130.80 & 32.5469 & 30.56782 & 934.392 & 1.492 & 2.512 \\
\hline June & 32 & 0.00 & 8.20 & 0.8906 & 2.20591 & 4.866 & 2.782 & 6.785 \\
\hline July & 32 & 0.00 & 0.00 & 0.0000 & 0.00000 & 0.000 & . & . \\
\hline August & 32 & 0.00 & 12.60 & 0.8719 & 2.52001 & 6.350 & 3.902 & 16.283 \\
\hline September & 32 & 0.00 & 37.40 & 5.6375 & 9.25327 & 85.623 & 2.067 & 3.954 \\
\hline October & 32 & 0.10 & 159.90 & 37.1344 & 46.62149 & 2173.563 & 1.599 & 1.438 \\
\hline November & 32 & 12.10 & 215.90 & 98.3313 & 57.31738 & 3285.282 & 0.579 & -0.480 \\
\hline December & 32 & 10.40 & 449.70 & 146.9281 & 87.30746 & 7622.593 & 1.445 & 3.518 \\
\hline Total & 32 & 523.40 & 1203.80 & 780.9375 & 170.00112 & $28,900.379$ & 0.406 & -0.242 \\
\hline Average & 32 & 43.62 & 100.32 & 65.0794 & 14.16687 & 200.700 & 0.406 & -0.242 \\
\hline
\end{tabular}

Table 4. Monthly maximum temperature in Igunga districts from 1985 to 2016.

\begin{tabular}{|c|c|c|c|c|c|c|c|c|c|}
\hline 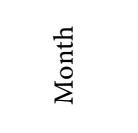 & Z & 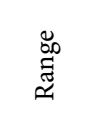 & 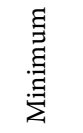 & 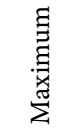 & $\sum^{\Xi}$ & 昰 & 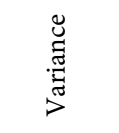 & 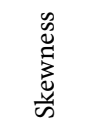 & 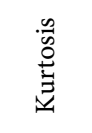 \\
\hline January & 32 & 261.90 & 27.10 & 28.90 & 37.7906 & 45.85650 & 2102.819 & 5.651 & 31.951 \\
\hline February & 32 & 273.70 & 28.30 & 30.20 & 38.6750 & 48.06843 & 2310.574 & 5.650 & 31.950 \\
\hline March & 32 & 4.40 & 28.40 & 32.80 & 30.2750 & 1.18049 & 1.394 & 0.575 & -0.298 \\
\hline April & 32 & 3.20 & 28.20 & 31.40 & 29.7969 & 0.82442 & 0.680 & 0.114 & -0.600 \\
\hline May & 32 & 3.80 & 27.70 & 31.50 & 29.8750 & 0.93980 & 0.883 & -0.641 & 0.053 \\
\hline June & 32 & 2.00 & 28.90 & 30.90 & 30.0281 & 0.45524 & 0.207 & -0.033 & 0.144 \\
\hline July & 32 & 1.70 & 29.20 & 30.90 & 29.9844 & 0.43782 & 0.192 & 0.341 & -0.620 \\
\hline August & 32 & 2.30 & 29.30 & 31.60 & 30.8875 & 0.46887 & 0.220 & -1.260 & 2.979 \\
\hline September & 32 & 2.10 & 31.40 & 33.50 & 32.4125 & 0.53627 & 0.288 & 0.273 & -0.189 \\
\hline October & 32 & 3.50 & 30.10 & 33.60 & 32.7375 & 0.72768 & 0.530 & -1.924 & 5.013 \\
\hline November & 32 & 9.50 & 24.00 & 33.50 & 31.0344 & 1.76847 & 3.127 & -1.985 & 7.080 \\
\hline December & 32 & 6.80 & 26.80 & 33.60 & 29.9938 & 1.57089 & 2.468 & 0.623 & 0.359 \\
\hline Average & 32 & 1.70 & 29.70 & 31.40 & 30.5781 & 0.41793 & 0.175 & -0.141 & -0.285 \\
\hline
\end{tabular}

mean monthly rainfall followed by January, March and April with recorded values of $141.35 \mathrm{~mm}, 116.59 \mathrm{~mm}, 136.71 \mathrm{~mm}$ and $109.42 \mathrm{~mm}$ respectively, while February, May, October and November recorded the lowest values of average rainfall with values of $95.6 \mathrm{~mm}, 33.4 \mathrm{~mm}, 34.4 \mathrm{~mm}$ and $97.47 \mathrm{~mm}$, respectively 
(Table 1). From this point of view, in Kishapu the maximum and the minimum rainfall for the study period (1987-2016) were $449.70 \mathrm{~mm}$ and $37.4 \mathrm{~mm}$ in December and September respectively. This is a typical trend for the semi-arid regions as defined in this study in which the lower limit for mean annual rainfall is $200 \mathrm{~mm}$ and the upper limit is $900 \mathrm{~mm}$ [16] [23].

The spatial distributions of precipitation indicate low rainfall variability with the maximum average of $102.20 \mathrm{~mm}$. Table 1 shows that the monthly rainfall variance in the amount of rainfall decreases from 6935.39 in December to 2570.56 in April. Most of the area in Kishapu District is characterised by high incidences of droughts. A distinctive decrease in the amount of rainfall in April suggests an earlier rainfall cessation, which shortens the length of the crop growing season; hence affecting proper maturation of crops and pastures. Also the apparent decrease of rainfall in Kishapu District for the pasr 30 years as indicated graphically in the rainfall trends, implies that rainfall is drastically reduced during February to April the critical crop growing period as a result of the current ongoing climate variability and change. The implication of both effects to the period is to reduce the productivity of crops and pastures. [35] have reported a decrease in productivity of maize, rice and sorghum in Tanzania due to climate change.

In Igunga District, the highest monthly mean rainfall was recorded in December, followed by January, March and April with recorded values of 146.9 $\mathrm{mm}, 110.0 \mathrm{~mm}, 138.13 \mathrm{~mm}$ and $112.98 \mathrm{~mm}$ of rainfall respectively, while February, May, August, and October recorded the lowest mean values of $97.4 \mathrm{~mm}$, $32.5 \mathrm{~mm}$ and $98.3 \mathrm{~mm}$ respectively (Table 3 ). Further, the maximum and the minimum monthly rainfall for the study period (1985-2016) were $449.9 \mathrm{~mm}$ and $65.4 \mathrm{~mm}$. respectively (Table 3). Statistical evidence shows that the monthly rainfall variance in the seasons is highest during December (7622.6), followed by January (3905.0) and the lowest during May (934.4) and March (1725.8), which indicates that there were significant variations in rainfall between the months. These results are in line with a study conducted by [36] when analyzing global monthly mean precipitation. It is important to note that variability of rainfall patterns leads to a redistribution of rainfall. Further, the precipitation had a decreasing trend over time, this led to an increase in extreme droughts and shortages of water during April to September. Therefore, an adaptation response to their perceptions would be appropriate and helpful to government efforts to avoid potential agricultural losses.

Figure 2 the trends in average annual rainfall in Kishapu from 1987 to 2016 and Igunga from 1985 to 2016 trends are presented. In the figure, indicates that the average annual rainfall has been decreasing from 1985 to 2016. Anomalous peaks in rainfall occurred in 1998 and 2006 most probably caused by El Nino events. The increase of rainfall which occurred in 1998 and 2006 was accompanied by flooding and destruction of infrasture and crops. So the high rainfall events led to starvation in Kishapu and Igunga areas. Otherwise, rainfall 


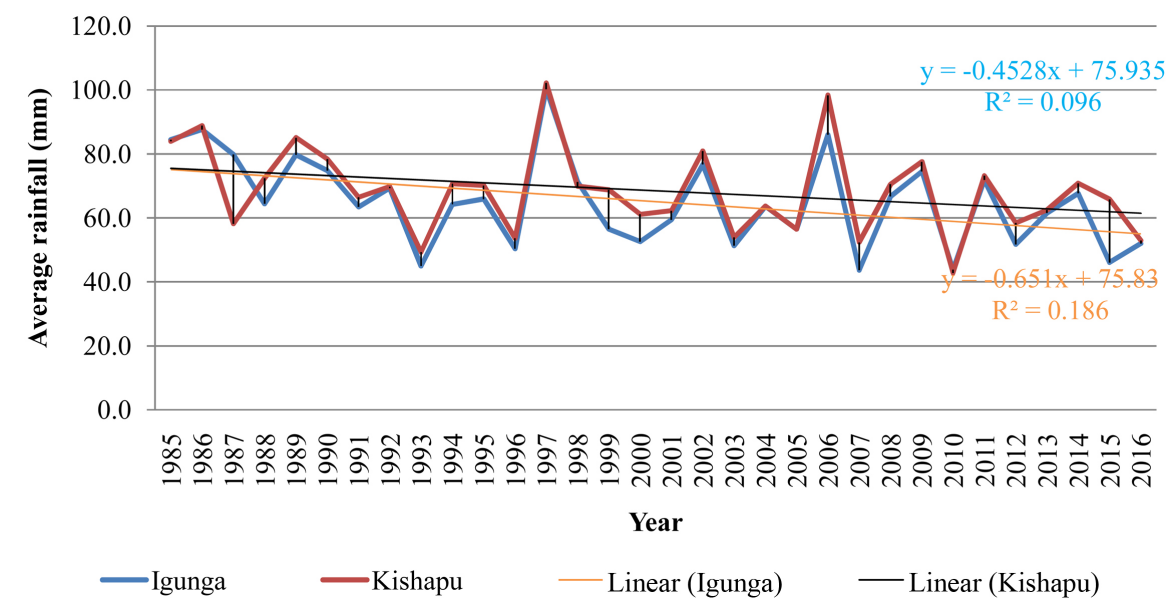

Figure 2. Trends in average annual rainfall in Kishapu and Igunga from 1985 to 2016.

has had a consistent falling pattern. Consistent rainfall patterns suggest that it rained at the time farmers and agro-pastoralists expected it to rain [23]. Nevertheless, rainfall variability, punctuating the general trend, can be beneficial when the increasing annual rainfall trend exceeds the range for semi-arid areas. The common situation for Igunga and Kishapu districts is that there was seasonal rainfall variability in both districts and the crop growing season normally began November and went on to the end of January.

In Kishapu District, temperature on the other hand, shows little variation with increasing trends in terms of minimum and maximum temperature. Table 2 shows that October and December are the two months that indicate the highest temperature, implying that it was the hottest months throughout the period between 1987 and 2016, while the lowest temperatures were in April, July and August ranging from $31.5^{\circ} \mathrm{C}$ to $33.6^{\circ} \mathrm{C}$ throughout during the period under consideration. The daytime temperature data are negatively skewed to the left $(-0.610)$, indicating that there are variations on temperature between months.

In Igunga District, the highest daytime temperature occurred in the months of October, November and December, while the lowest occurred in the months of November and January ranging from $24.0^{\circ} \mathrm{C}$ to $33.6^{\circ} \mathrm{C}$ (Table 4). Results showed that the mean maximum temperature for Igunga district in Tabora region, was $38.67^{\circ} \mathrm{C}$ in February over the period between 1985 and 2016. This implies that the periods of highest temperature were also dry periods. It also implies that the increase in maximum temperature was accompanied by decreasing amount of rainfall in Igunga District in particular (Table 1). Maximum temperature is normally recorded during the day time, thus its increase most probably reduces soil moisture through evaporation and evapotranspiration, which in turn negatively affects crop and pasture development. This has been also reported in Singida District, Tanzania by [23].

The findings in Table 1 and Table 3, revealed that the long-term mean was $146.9 \mathrm{~mm}$ and $141.35 \mathrm{~mm}$ per year in Igunga and Kishapu districts respectively, throughout the period under consideration. It was noticed that while rainfall had 
a decreasing trend (Figure 2), maximum temperatures were increasing (Figure 3). However, in the literature report [9] the semi-arid areas have rainfall which ranges between 200 and $800 \mathrm{~mm}$ per annum [9]. From the findings the amount of rainfall in Kishapu and Igunga does not exceed this average amount of rainfall. Rainfall variability has not been beneficial because the anomalous high irregular annual rainfall events have not exceeded the range for semi-arid regions, which suggest that the crops and livestock were at risk. Generally, rainfall data collected from Igunga and Kishapu rainfall metereological stations revealed decreasing linear trend over time. Results also showed annual variability over time with $\mathrm{R}^{2}$ of 0.096 and 0.1863 in Igunga and Kishapu respectively. This translates into $0.96 \%$ and $18.6 \%$ of annual rainfall variability between 1985 and 2016 (Figure 2). This implies that $0.96 \%$ and $18.6 \%$ of the rainfall variability was associated with change in time, while the rest variance can be explained by other factors. Similar results of rainfall variability have been reported in semi-arid areas in Singida, Tanzania [23].

Two peaks in mean annual rainfall occurred in $1998(105 \mathrm{~mm})$ and 2006 (100 $\mathrm{mm}$ ); these were associated with El-Nino events which caused floods, destroying houses in villages, towns, roads and other infrastructure. On the hand, in 1993, 2007 and 2010 the rainfall pattern indicates that there was a La Nina which brought in severe drought in the area. Several other years with drought are clearly shown in 1996, 2003, 2012 and 2015. The falling mean rainfall pattern is affecting the replenishment of fresh water supplies in Kishapu and Igunga districts, leading to the drying of certain rivers and in others reduced flow.

However, statistical evidence provided by meteorological agency in Igunga and Kishapu shows an increase in temperature. Both trends for maximum and minimum temperature were increasing over time. This implies that daytime surface temperature increased over time in both Igunga and Kishapu. Trends show that the maximum temperature increased in 2003 and 2006 throughout the period between 1987 and 2016. The rest of the years show fluctuating trends over the same period suggesting temperature variability in Kishapu including Igunga District. This study argues that, higher temperatures are intensifying

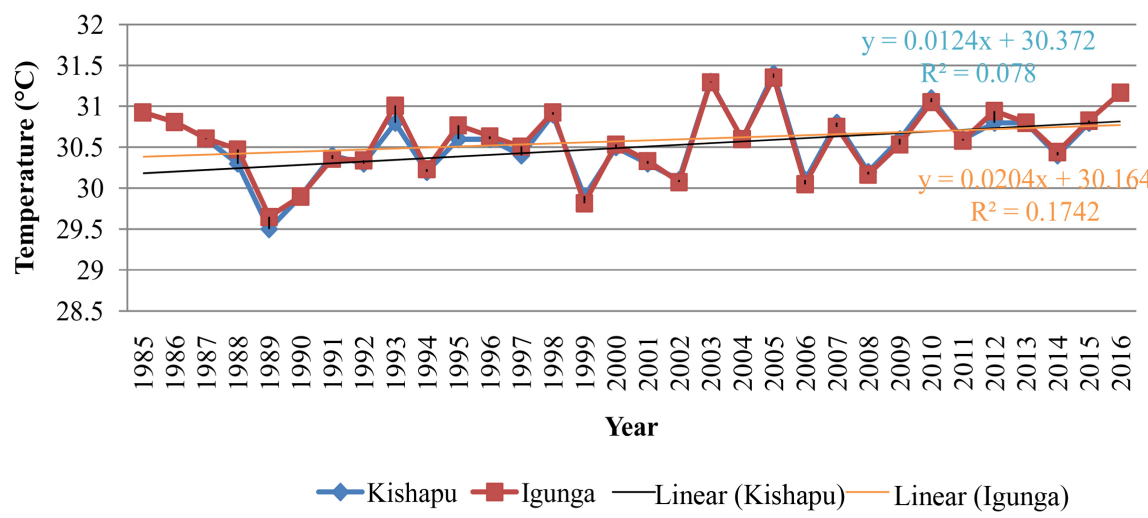

Figure 3. Trends in an average annual maximum temperature in Kishapu and Igunga from 1985 to 2016. 
evapo-transpiration and reducing soil moisture available for crops, particularly during the planting season. This phenomenon is most probably threatening crop and pasture development and productivity. Water sources are drying up, thus adversely affecting smallholder farmers and agro-pastoralists whose livelihoods largely depends on the rain-fed farming system. Seasonal variability of rainfall and temperature was similarly reported by [24] and [35] at the national level in Tanzania.

Figure 3 in Kishapu the Inter-annual variability revealed $\mathrm{R}^{2}$ of 0.078 for annual temperature. This translates into moderate temperature variability of $7.8 \%$ related to changes in time. For Igunga, the $\mathrm{R}^{2}$ was 0.1724 , which translates into strong temperature variability of $17.24 \%$ over time. However, in Kishapu change in time explained temperature variability by $7.8 \%$ and in Igunga temperature variability by $17.24 \%$. This suggests strong annual trends for temperature variability for the period under concern. Table 5, the p-value was $0.007(\mathrm{P}>0.005) \mathrm{im}$ plying that the change was not statistically significant at $5 \%$ level of significance. The $\mathrm{R}^{2}$ was 0.1195 , translating into $0.1 \%$ of the inter-annual temperature variability that was associated with change in time between 1985-2016.

Further, the correlation between temperature and time is significant as shown by the significance of Pearson Correlation test at the $1 \%$ probability level (Table 5). The result indicates that there is no statistical significant trend in the aveage temperature over time in the study areas. The R-squared statistic also indicates a weak relationship between the variables average temperature and time (season).

\subsection{Rainfall and Temperature Variation during Growing Season in Kishapu and Igunga}

Annual crop yields for five major crops: maize, sorghum, cotton, sunflower and

Table 5. Statistical analysis average temperature over time (year) in the study area.

\begin{tabular}{|c|c|c|c|c|c|c|c|c|c|}
\hline \multicolumn{10}{|c|}{ Modal Summary } \\
\hline \multirow{2}{*}{ Model } & \multirow{2}{*}{$\mathrm{R}$} & \multirow{2}{*}{$\mathrm{R}^{2}$} & \multirow{2}{*}{ Adjusted $\mathrm{R}^{2}$} & \multirow{2}{*}{$\begin{array}{l}\text { Std. Error of } \\
\text { the Estimate }\end{array}$} & \multicolumn{3}{|c|}{ Change Statistics } & \multirow[b]{2}{*}{ df2 } & \multirow[b]{2}{*}{ Sig. F Change } \\
\hline & & & & & $\mathrm{R}^{2}$ Change & F Change & df1 & & \\
\hline 1 & 0.340 & 0.116 & 0.101 & 0.39352 & 0.116 & 7.717 & 1 & 59 & 0.007 \\
\hline \multicolumn{10}{|c|}{ ANOVA $^{1 \mathrm{a}}$} \\
\hline Model & & & & $\begin{array}{l}\text { Sum of } \\
\text { Squares }\end{array}$ & $\mathrm{df}$ & $\begin{array}{l}\text { Mean } \\
\text { Square }\end{array}$ & $\mathrm{F}$ & Sig. & \\
\hline \multirow[t]{3}{*}{1} & & & Regression & 1.195 & 1 & 1.195 & 7.717 & $0.007^{2 b}$ & \\
\hline & & & Residual & 9.136 & 59 & 0.155 & & & \\
\hline & & & Total & 10.331 & 60 & & & & \\
\hline \multicolumn{10}{|c|}{ Correlations } \\
\hline & & \multicolumn{2}{|c|}{$\begin{array}{c}\text { Pearson } \\
\text { Correlation }\end{array}$} & \multicolumn{2}{|c|}{ Sig. (1-tailed) } & \multicolumn{2}{|c|}{$\mathrm{N}$} & & \\
\hline & & Temp & Year & Temp & Year & Temp & Year & & \\
\hline $\begin{array}{l}\text { Ave } \\
\text { Tempe }\end{array}$ & $\begin{array}{l}\text { rage } \\
\text { erature }\end{array}$ & 1.000 & 0.340 & . & 0.004 & 61 & 61 & & \\
\hline
\end{tabular}

${ }^{1}$ Dependant variable: Average temperature; ${ }^{2}$ Predictors: (Constant) year. 
cowpeas were obtained from the respondents in Kishapu and Igunga Districts. All crops have one growing season in both districts. The growing seasons for the crops are determined by the major planting and harvest months. It was found that the planting and harvesting days varied from year to year depending on weather conditions.

Rainfed farming in Igunga and Kishapu resolves around three major activities: planting, weeding and harvesting, which are linked directly to rainfall events. The period of planting is the time of greatest uncertainty and risk because planting decisions largely assemble the other activities and may not easily be implemented after certain time.

Results in Table 1 also show that in Kishapu District the TMA station has recorded rainfall over the past 30 years. This indicates high variability in monthly rainfall especially in the months of October, November and December (Figure 4). This annual variability in monthly rainfall coincides with the main sowing period i.e., November and December. In addition, rainfall records in February suggest a dry spell, which shortens the length of the crop growing season, thereby affecting proper maturity of crops and pastures. In other words, the decrease trend implies that rainfall progressively decreases during the critical crop growing period. In semi-arid regions like Kishapu and Igunga, where agriculture is predominately rainfed, variability in monthly rainfall during the cropping season increases the vulnerability of crop production, leading to reduced crop yields and crop failures. The implication of both effects is to reduce the productivity of crops and pastures. [23], for example, have reported a decrease in productivity for maize, cotton, sorghum and sunflower in Shinyaga due to climate variability.

The trend analysis of rainfall data (Figure 4) indicates that there is highest variability of rainfall within months during the crop growing season; the more prounounced decrease being in October during the onset of the growing period.

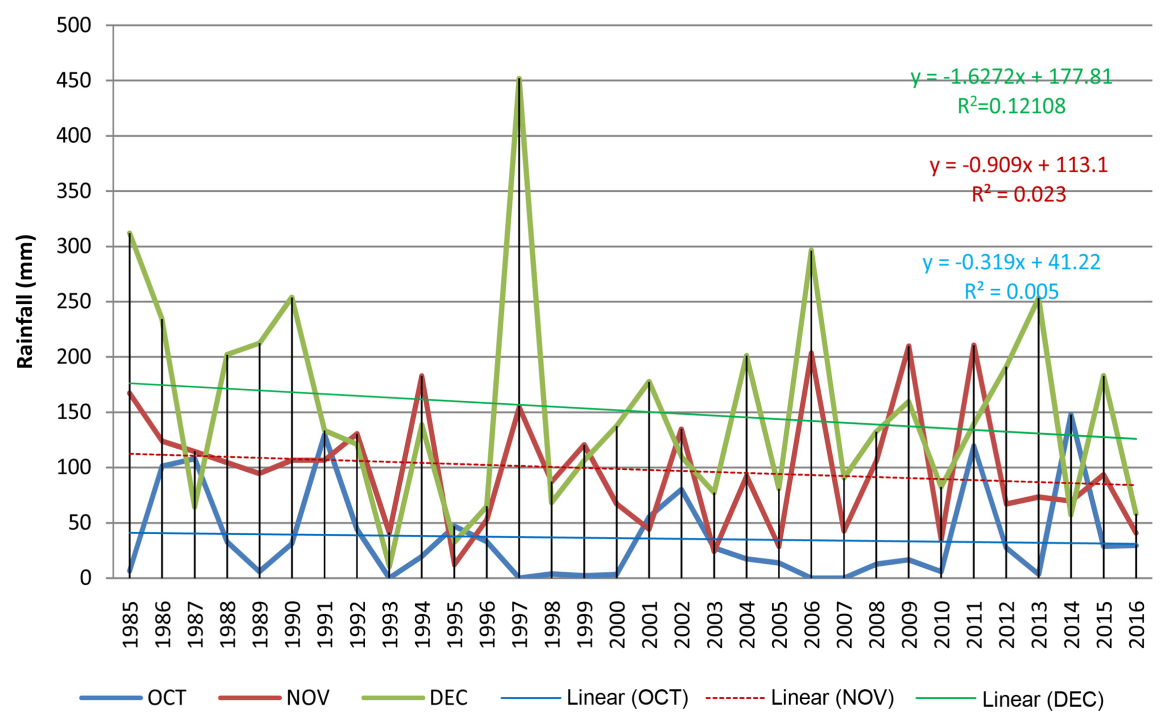

Figure 4. Rainfall trends during growing season in Kishapu (October to December). 
This indicates that the onset and end of rainfall during the growing period has become more erratic and unpredictable. The observations under similar climatic conditions are in broad agreement with those reported by [37] and [38]. However, the months of October and November show a continuous decrease in amount of rainfall throughout the period under consideration. Variability of rains and fluctuating decreasing trends during the crop growing season suggest presence of seasonal rainfall variability. Similar observations have been reported by [23] in a study of climate variability in Shinyanga and Singida. Intra-seasonal factors, such as timing of the onset of first rains affecting the crop planting regimes [39], the distribution and length of rain during the growing season [40] and effectiveness of rains in each precipitation event [39], are the real criteria that determine the effectiveness and success of farming. The clear decreasing trend in February implies that rainfall was decreasing during the critical crop growing period. The implication of both effects (which occur in November and February) is to reduce the productivity of crops and pastures in areas under consideration. The $\mathrm{R}^{2}$ was, $0.0434,0.043,0.0284$ in October, November and December respectively of rainfall variability and that variability were higher at Kishapu station compared to Igunga rainfall station.

Furthermore, in Figure 5, findings revealed that the linear rainfall trend in Kishapu was decreasing over time like Igunga rainfall anomaly trend. However, the $\mathrm{R}^{2}$ was 0.00051 and 0.0237 in October and November respectively of rainfall variability and that variability were higher at Kishapu station compared to Igunga rainfall station. According to [23], climate variability and change occurred through increased rainfall unpredictability; increased frequency of drought; increased duration of dry spells and warmings. Such climatic changes increased farmers and agro-pastoralist mobility in search for water and pasture for livestock and also brought in changes of crop varieties to be grown.

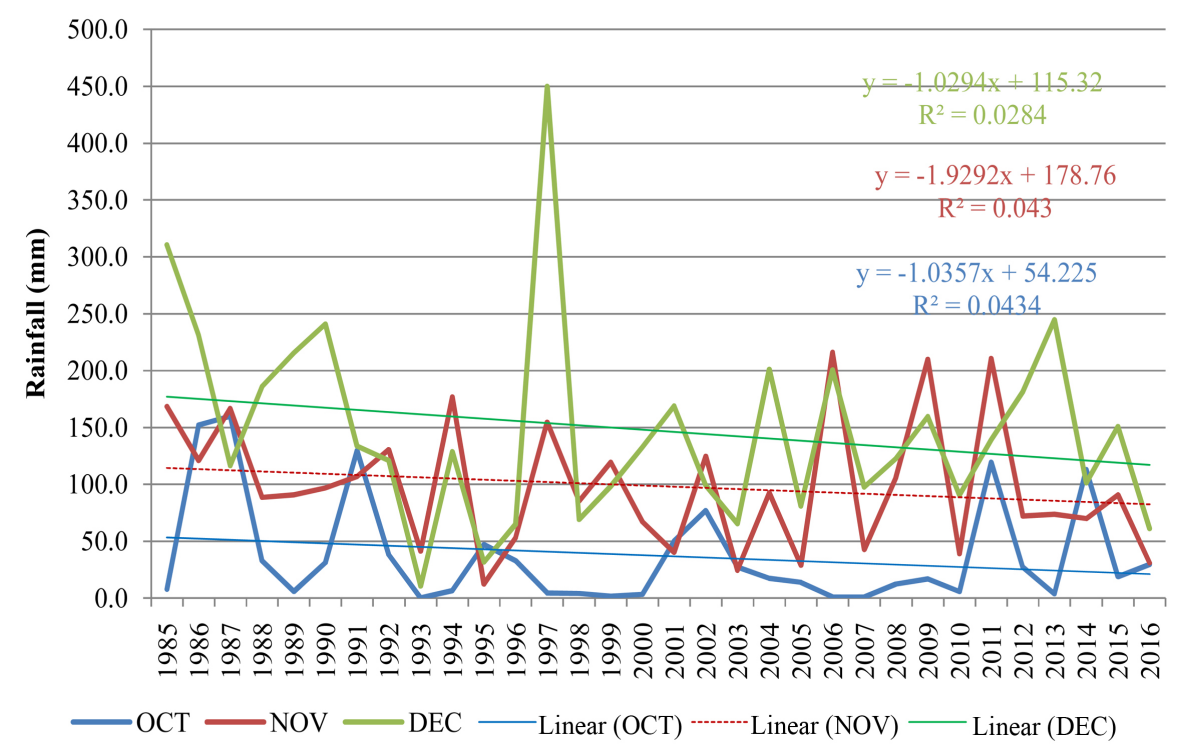

Figure 5. Rainfall trends during growing season in Igunga (October to December). 


\section{Conclusions and Recommendations}

This paper examined trends in seasonal variability of rainfall and temperature in Igunga and Kishapu districts. Statistically the temperature showed an increased trend while precipitation was characterized by large inter-annual variability and a decreased amount during rainy season. Low levels of precipitation were found from June to September while high levels of precipitation occurred in December. These trends were confirmed by local perceptions, found from qualitative study. Specifically the study assessed trends in the monthly temperature and rainfall variability. Based on the results and discussions, the paper concludes that, the meteorological data show increasing average temperatures and decreasing annual rainfall patterns for the past 31 years examined (1985 and 2016). The analysis indicates that the onset and end of rainfall during the growing period has become more erratic and unpredictable since 1985. Annual rainfall variability trends, however, increased minimally indicating that annual variability was somewhat a common feature in the study districts. The analysis indicated a shift on the onset of long rains from October/November to December/January with shortening of rainfall period and increased frequency of drought. As far as temperature was concerned, it had an increasing trend, and also the maximum temperatures showed considerable variability, a typical characteristic of semi-arid areas. Further, whereas annual variability showed rainfall variability in both districts, seasonal trends showed considerable rainfall and temperature variability within and between seasons. When analyzing climate variability, it is therefore important to consider both seasonal and inter-annual variability so as to have a clear understanding regarding the degree of climate variability and change.

Based on the results and conclusion, the paper recommends that the local government authorities and other independent initiatives should be directed towards the support of crop and livestock adjustments in order to cushion the impacts of rainfall and temperature variability during critical periods for growing of crops and pastures. Capacity building to the farmers and livestock keepers through training is still needed especially on appropriate adaptation strategies to climate change. Such strategies can be applied to address risks caused by insufficient rainfall, higher day time temperature, as well as rainfall and temperature variability, which have been demonstrated in this paper. Climate change policies should be actively incorporated in all developmental plans. For example water harvesting can be promoted for irrigation to supplement rain-fed agriculture and for consumption by people and livestock in both districts; as well as setting up policies for animal breeding and crop varieties in the study areas for providing highly tolerant breeds, pastures and crop varieties tolerant to drought.

\section{Conflicts of Interest}

The authors declare no conflicts of interest regarding the publication of this paper. 


\section{References}

[1] Mary, A.L. and Majule, A.E (2009) Impacts of Climate Change, Variability and Adaptation Strategies on Agriculture in Semi Arid Areas of Tanzania: The Case of Manyoni District in Singida Region, Tanzania. African Journal of Environmental Science and Technology, 3, 206-218. http://www.academicjournals.org/AJEST

[2] Mongi, H., Majule, A.E. and Lyimo, J.G. (2010) Vulnerability and Adaptation of Rain Fed Agriculture to Climate Change and Variability in Semi-Arid Tanzania. African Journal of Environmental Sciences and Technology, 4, 371-381. https://doi.org/10.5897/AJEST09.207

[3] Blench, R. and Marriage, Z. (1999) Drought and Livestock in Semi-Arid Africa and Southwest Asia. Oversees Development Institute, London.

[4] Burke, M.B., Lobell, D.B. and Guarino, L. (2009) Shifts in African Crop Climates by 2050, and the Implications for Crop Improvement and Genetic Resources Conservation. Global Environmental Change, 19, 317-325. https://doi.org/10.1016/j.gloenvcha.2009.04.003

[5] Lema., M.A and Majule, A.E. (2009) Impacts of Climate Change, Variability and Adaptation Strategies on Agriculture in Semi-Arid Areas of Tanzania: The Case Manyoni District in Singida Region, Tanzania. Africa Journal Science Technology, 3, 206-218.

[6] Swai, O.W., Mbwambo, J.S. and Magayane, F.T. (2012) Gender and Adaptation Practices to the Effects of Climate Change in Bahi and Kondoa Districts, Dodoma Region, Tanzania. Journal of Sustainable Development, 5, 65-77. https://doi.org/10.5539/jsd.v5n12p65

[7] Lyimo, J.G. and Kangalawe, R.Y.M. (2010) Vulnerability and Adaptative Stratergies to the Impact of Climate Change and Variability: The Case of Rural Households in Semi-Arid Tanzania. Environmental Economics, 1, 89-97.

[8] Agrawala, S., Moehner, A., Hemp, A., Van Aalst, M., Hitz, S., Smith, J., Meena, H., Mwakifwamba, S.M., Hyera, T. and Mwaipopo, O.U. (2003) Development and Climate Change in Tanzania: Focus on Mount Kilimanjaro. Organization for Economic Co-Operation and Development (OECD), Paris, 72 p.

[9] Intergovernmental Panel on Climate Change (IPCC) (2007) Summary for Policymakers. In: Parry, M.L., Canziani, O.F., Palutikof, J.P., Van der Linden, P.J. and Hanson, C.E., Eds., Climate Change 2007: Impacts, Adaptation and Vulnerability. Contribution of Working Group II to the Fourth Assessment Report of the Intergovernmental Panel on Climate Change. Cambridge University Press, Cambridge, 7-22.

[10] Morton, J. (2007) The Impact of Climate Change on Smallholder and Subsistence Agriculture. Proceedings of the National Academy of Sciences of the United States of America, 104, 19680-19685. https://doi.org/10.1073/pnas.0701855104

[11] Paavola, J. (2008) Livelihoods, Vulnerability and Adaptation to Climate Change in Morogoro Region, Tanzania. Sustainability Research Institute, University of Leeds, Leeds.

[12] Kotir, J.H. (2010) Climate Change and Variability in Sub-Saharan Africa: A Review of Current and Future Trends and Impacts on Agriculture and Food Security. Environment, Development and Sustainability, 13, 587-605.

https://doi.org/10.1007/s10668-010-9278-0

[13] Roudier, P., Sultan, B., Quirion, P. and Berg, A. (2011) The Impact of Future Climate Change on West African Crop Yields: What Does the Recent Literature Say? 
Global Environmental Change, 21, 1073-1083.

https://doi.org/10.1016/j.gloenvcha.2011.04.007

[14] Intergovernmental Panel on Climate Change. (2014) Climate Change 2014: Mitigation of Climate Change. In: Field, C., Barros, V., Mach, K. and Mastrandrea, M., Eds., Contribution of Working Group II to the Fifth Assessment Report of the Intergovernmental Panel on Climate Change, Cambridge University Press, Cambridge. https://doi.org/10.1017/CBO9781107415416

[15] Quinn, C.H. and Ockwell, D. (2010) The Link between Ecological and Social Paradigms and the Sustainability of Environmental Management: A Case Study of Semi-Arid Tanzania. In: Lovett, J.C. and Ockwell, D., Eds., A Handbook of Environmental Management, Edward Elgar Publishing Ltd., Cambridge, 282-308.

[16] Huang, J., Guan, X. and Ji, F. (2012) Enhanced Cold-Season Warming in Semi-Arid Regions. Atmospheric Chemistry and Physics, 12, 5391-5398.

https://doi.org/10.5194/acp-12-5391-2012

[17] Exenberger, A. and Pondorfer, A. (2011) Rain, Temperature and Agricultural Production: The Impact of Climate Change in Su-Saharan Africa, 1961-2009. Working Papers in Economics and Statistics 2011-26 in Economics and Statistics, University of Innsbruck, $30 \mathrm{p}$.

[18] University of Dar es Salaam (1999) Rethinking Natural Resources Degradation in Semi-Arid Sub-Saharan Africa: The Case of Semi-arid Tanzania. University of Dar es Salaam, Dar es Salaam, 58 p.

[19] Tietjen, B. and Jeltsch, F. (2007) Semi-Arid Grazing Systems and Climate Change: A Survey of Present Modelling Potential and Future Needs. Journal of Applied Ecolo$g y, 44,425-434$. https://doi.org/10.1111/j.1365-2664.2007.01280.x

[20] United Republic of Tanzania (URT). (2007) National Adaptation Programmes of Action. Vice President's Office, Division of Environment, 52 p.

[21] Vetter, S. (2009) Drought, Change and Resilience in South Africa's Arid and Semi-Arid Rangelands. South Africa Journal of Science, 105, L29-L33. https://doi.org/10.4102/sajs.v105i1/2.35

[22] Midgrey, S., Dejene, A. and Mattick, A. (2012) Adaptation to Climate Change in Semi-Arid Environments: Experiences and Lessons from Mozambique. Food and Agricultural Organization, Rome, $84 \mathrm{p}$.

[23] Kabote, S.J., Mamiro, D., Synnevåg, G., Urassa, J.K., Mattee, A.Z., Mbwambo, J.S., Nombo, C.I., Masolwa, L.W. and Chingonikaya, E.E. (2013) Inter-Annual Anomaly and Seasonal Variability of Rainfall and Temperature in Selected Semi-Arid Areas of Tanzania. Journal of Continuing Education and Extension, 4, 295-317.

[24] McSweeney, C., New, M. and Lozano, G. (2010) The UNDP Climate Change Country Profiles, Tanzania. Improving the Accessibility of Observed and Projected Climate Information for Studies of Climate Change in Developing Countries: http://country-profiles.geog.ox.ac.uk

[25] Sarr, B. (2012) Present and Future Climate Change in the Semi-Arid Region of West Africa: A Crucial Input for Practical Adaptation in Agriculture. Atmospheric Science Letters, 13, 108-112. https://doi.org/10.1002/asl.368

[26] Challinor, A., Wheeler, T., Garforth, C., Craufurd, P. and Kassam, A. (2007) Assessing the Vulnerability of Food Crop Systems in Africa to Climate Change. Climate Change, 83, 381-399. https://doi.org/10.1007/s10584-007-9249-0

[27] Moyo, M., Mvumi, B.M., Kunzekweguta, M., Mazvimavi, K., Craufurd, P. and Dorward, P. (2012) Farmer Perceptions of Climate Change and Variability in Semi-Arid Zimbabwe in Relation to Climatology Evidence. African Crop Science 
Journal, 20, 317-335.

[28] Igunga District Council (2009) Igunga District Socio-Economic Profile. Igunga District Council, $89 \mathrm{p}$.

[29] United Republic of Tanzania (2002) Population and Housing Census (2013). National Bureau of Statistics, Dar es Salaam.

[30] Mkwama, T. (2015) The Impact of Local Food Economies in Nutrition Status at Meso-Level: The Case of Kishapu District in Tanzania. Saint Augustine University of Tanzania, Mwanza.

[31] Kishapu District Council (2009) Kishapu District Socio-Economic Profile. Kishapu District Council.

[32] Rubanza, C.D.K., Shem, M.N., Bakengesa, S.S., Ichinohe, T. and Fujiyama, T. (2005) Content of Macro and Micro Minerals of Deferred Forages in Silvo-Pastoral Traditional Fodder Banks (Ngitiri) of Meatu District of Central North-Western Tanzania. Livestock Research for Rural Development, 17, Article No. 141.

[33] Hashim, M., Ismail, W.R., Nayan, N., Ngah, M.S.Y.C. and Ibrahim, M.H. (2012) Analysis of Rainfall Trend in Ipoh City, Perak 1970-2007. Journal of Social Sciences and Humanities, 7, 149-164.

[34] Issahaku, A., Campion, B.B. and Edziyie, R. (2016) Rainfall and Temperature Changes and Variability in the Upper East Region of Ghana. Earth and Space Science, 3, 284-294. https://doi.org/10.1002/2016EA000161

[35] Rowhani, P., Lobell, D.B., Linderman, M. and Ramankutty, N. (2011) Climate Variability and Crop Production in Tanzania. Agricultural and Forest Meteorology, 151, 449-460. https://doi.org/10.1016/j.agrformet.2010.12.002

[36] Westra, S., Alexander, L.V. and Francis, W.Z. (2013) Global Increasing Trends in Annual Maximum Daily Precipitation. Journal of Climate, 26, 3904-3918. https://doi.org/10.1175/JCLI-D-12-00502.1

[37] Yanda, P.Z., Olson, J. and Moshy, P. (2008) Climate Change Vulnerability Impacts and Adaptation in Tanzania. CLIP Working Paper. Institute of Resource Assessment, University of Dar es Salaam, Tanzania.

[38] Majule, A.E. (2008) Climate Change and Variability: Impacts on Agriculture and Water Resources and Implications for Livelihood in Selected Basins. Towards Climate Change Adaptation. Internationale WeiterBildung und Entwicklung gGmbh, Germany.

[39] Ouma, J.O., Olang, L.O., Ouma, G.O., Oludhe, C., Ogallo, L. and Artan, G. (2018) Magnitudes of Climate Variability and Changes over the Arid and Semi-Arid Lands of Kenya between 1961 and 2013 Period. American Journal of Climate Change, 7, 27-39. https://doi.org/10.4236/ajcc.2018.71004

[40] Usman, M.T. and Reason, C.J.C. (2004) Dry Spell Frequencies and Their Variability over Southern Africa. Climate Research, 26, 199-211. https://doi.org/10.3354/cr026199 